\title{
BIOLOGICAL RESISTANCE OF THERMALLY TREATED Corymbia citriodora (Hook.) K.D. Hill \& L.A.S. Johnson E Pinus taeda L. WOODS AGAINST XYLOPHAGOUS TERMITES ${ }^{1}$
}

Juarez Benigno Paes²*, Pedro Gutemberg de Alcântara Segundinho², Allan Ewerton Rezende Euflosino², Márcio Rogério da Silva ${ }^{4}$, Carlito Calil Junior ${ }^{5}$ and André Luis Christoforo ${ }^{6}$

\footnotetext{
${ }^{1}$ Received on 08.12.2014 accepted for publication on 29.10.2015.

${ }^{2}$ Universidade Federal do Espírito Santo, Departamento de Ciências Florestais e da Madeira, Jerônimo Monteiro, ES - Brasil. E-mails:<jbp2@uol.com.br> and <p_gutemberg2001@yahoo.com.br>.

${ }^{3}$ Universidade Federal do Espírito Santo, Programa de Pós Graduação em Ciências Florestais, Jerônimo Monteiro, ES - Brasil. E-mail: <allan_ewerton@hotmail.com>.

${ }^{4}$ Universidade de São Paulo, Programa de Pós-Graduação em Ciências e Engenharia de Materiais, São Carlos, SP - Brasil. E-mail: <marciomr@sc.usp.br>.

${ }^{5}$ Universidade de São Paulo, Departamento de Estruturas, São Carlos, SP - Brasil. E-mail: <calil@sc.usp.br>.

${ }^{6}$ Universidade Federal de São Carlos, Departamento de Engenharia Civil, São Carlos, SP - Brasil. E-mail: <christoforoal@yahoo.com.br>.

*Corresponding author.
}

\begin{abstract}
This research aimed to evaluate the effect of the thermal-treated temperature to improvement of Corymbia citriodora and Pinus taeda wood resistance to the xylophagous termite Nasutitermes corniger, into forced feeding assay. The wood thermally treated was performed at temperatures of 160, 180, 200, 220, $240^{\circ} \mathrm{C}$. For Pinus taeda, the temperature of $260^{\circ} \mathrm{C}$ was also used. Three boards of $6 \times 16 \times 56 \mathrm{~cm}$ (thickness $\times$ width $\mathrm{x}$ length) were used for each temperature. After being thermally treated, the boards were transformed into samples of $2.54 \times 2.54 \times 0.64 \mathrm{~cm}$ (longitudinal $\times$ radial $\times$ tangential). The experiment was kept in a climatized room $\left(25 \pm 2{ }^{\circ} \mathrm{C}\right.$ and $65 \pm 5 \%$ of relative humidity), for 28 days. For Corymbia citriodora, the thermal treatment at 220 and $240^{\circ} \mathrm{C}$ improved the resistance to the termite. For Pinus taeda, the resistance improvement occurred at 240 and $260^{\circ} \mathrm{C}$. The temperature of $160^{\circ} \mathrm{C}$ caused a decrease in the natural durability of both species.
\end{abstract}

Keywords: Thermal treatment; Natural resistance; No chose feeding assays.

\section{RESISTENCIA BIOLOGICA DAS MADEIRAS DE Corymbia citriodora (Hook.) K.D. Hill \& L.A.S. Johnson E Pinus taeda L. TRATADAS TERMICAMENTE CONTRA CUPINS XILOFAGOS}

\begin{abstract}
RESUMO - Esta pesquisa teve como objetivo avaliar o efeito do tratamento térmico nas madeiras de Corymbia citriodora e de Pinus taeda visando sua melhorar a resistência ao cupim xilofagos Nasutitermes corniger, por meio de ensaios de alimentação forçada. As temperaturas utilizadas nos tratamentos térmico das madeiras foram 160, 180, 200, 220 e $240{ }^{\circ} \mathrm{C}$. Para o Pinus taeda também foi empregada a temperatura de $260^{\circ} \mathrm{C}$. Três pranchas de $6 \times 16 \times 56 \mathrm{~cm}$ (espessura $\times$ largura $\times$ comprimento) foram confeccionadas para avaliar os efeitos de cada temperatura investigada. Depois de tratadas, as pranchas forma transformadas em amostras de dimensões 2,54 $\times 2,54 \times 0,64$ centímetros (longitudinal $\times$ radial $\times$ tangencial radial). O experimento foi mantidos numa sala climatizada $\left(25 \pm 2{ }^{\circ} \mathrm{Ce} 65 \pm 5 \%\right.$ de umidade relativa) durante 28 dias. Para a madeira de Corymbia citriodora, o tratamento térmico de 220 e $240{ }^{\circ} \mathrm{C}$ aumentou a resistência ao ataque do cupim. Para as madeiras de Pinus taeda, a melhoria da resistência ocorreu a 240 e $260^{\circ} \mathrm{C}$. A temperatura de $160{ }^{\circ} \mathrm{C}$ provocou um decréscimo na resistência natural de ambas as espécies.
\end{abstract}

Palavras-chave: Tratamento térmico; Resistência natural; Ensaios de alimentação forçada. 


\section{INTRODUCTION}

The biological resistance of the wood is interpreted as its ability of resisting deteriorating actions of biological organisms (GOMES; FERREIRA, 2002). The same authors define classes as high, medium or low wood resistance to these organisms.

In order to use the wood as building material, the biological durability is one of the priorities of greatest importance (OLIVEIRA, 1998). Knowing about the natural resistance of the wood is very important to recommend the most appropriate use for the material, avoiding unnecessary expenses with maintenance or substitution of deteriorated pieces (PAES et al., 2004).

Usually, toxic substances are impregnated inside the wood to increase its biological durability. Although the emission of active ingredients is low during the fixation of chemical products to the wood, this technique is not usually seen as friendly. Therefore, the increase in the wood durability due to thermal modification or thermal treated is usually more acceptable (HOMAN et al., 2000).

Thermal modification can be defined as a precarbonization process, which is developed at the endothermic phase of the wood. Under these temperature conditions, some wood compounds are degraded, especially hemicellulose, as they are more sensitive to high temperatures. Acetic acid and phenolic fractions are also degraded under these conditions (RENDEIRO et al., 2008).

Thus, thermally treated wood is obtained through a thermal degradation process, in which wood constituents are usually degraded with no oxygen or lack of air, possibly characterizing it as controlled pyrolisys that is interrupted before reaching the level of an exothermic reaction (which begins at approximately $280^{\circ} \mathrm{C}$ ), when spontaneous combustion of the wood takes place (BORGES; QUIRINO, 2004).

The desired changes caused by the thermal treatment of the wood begin at approximately $150^{\circ} \mathrm{C}$ and go on as the temperature goes up (GUNDUZ et al., 2009). However, according to Esteves; Pereira (2008), the temperature, at which degradation begins, depends on the molecular mass and crystallinity of the wood constituents.

The alterations are followed by many desirable changes on the physical properties, including the contraction and swelling reduction, decrease in the moisture balance content, improvement in the weathering resistance, dark decorative color and higher resistance to decomposition (BORGES; QUIRINO, 2004; KORKUT; BEKTAS, 2008).

During the process of wood thermal modification, cracks might be observed and the cell wall structure might be partially degraded, therefore, individual optimizations of these parameters can be separately conducted for each type of wood and even the same type of wood can be treated in different conditions, possibly leading to significant differences in cell structure and, thus, requiring different treatment conditions (PONCSÁK et al., 2006).

Among the uses of thermally treated wood, flooring, installation of sound proof walls, floors, terraces, garden furniture, door and window casings and house furniture can be mentioned (DUCHEZ; GUYONNET, 2002). Under these use conditions, the wood is susceptible to the action of subterranean termites. In order to supply the growing demand for more resistant wood when it comes to xylophagous organisms and to reduce the pressure on native forests, an appealing option is the use of thermal modification for species that are planted and grow fast.

As a result, thermal treatment comes as an alternative to improve the use of wood that is considered to bring problems regarding technology, diversifying the use of such woods and broadening its economical potential, issues that concern the use of wood from Pinus and Eucalyptus (Corymbia), which although they are available in commercial scale, they are limited when it comes to their use, as one or more of their properties is not suitable for specific purposes.

This study aimed to verify the effect of temperature on thermal modification in order to improve the resistance of Corymbia citriodora and Pinus taeda to the xylophagous termite Nasutitermes corniger into force feeding assay.

\section{MATERIALAND METHODS}

\subsection{Origin and thermal modification of the woods}

The Pinus taeda trees were originally from Jaguariaiva region, Paraná State, Brazil. The Corymbia citriodora were originally from Brotas region, São Paulo State, Brazil. For both species, trees from 18 to 20 years old were used. 
Older trees were used with the objective of decreasing the problems resulted from internal tensions, present in younger individuals, avoiding excessive cracks during the process of wood thermal modification.

The thermal modification process was performed at the Laboratory of Chemistry, Cellulose and Energy, of the Agriculture School “Luiz de Queiroz", University of São Paulo, in Piracicaba, São Paulo, Brazil.

The heat rate used in this study was $0.033^{\circ} \mathrm{C} \mathrm{min}^{-1}$, based on the experiments with broadleaved conifers by Pincelli et al. (2002). This heat rate was adopted with the objective of avoiding cracks and on the wood of the studied species.

The thermal treatment began at environmental temperature $\left(30^{\circ} \mathrm{C}\right)$ and, the time to increase the temperature was $40 \mathrm{~min}$, being necessary different temperatures for the beginning of the ramp, due to the different species and the different temperature ranges that were adopted (Table 1).

The initial moisture of the wood samples for the thermal treatment was $12 \pm 2 \%$. The time the samples were kept in the oven after reaching the final temperature of the ramp was called final plateau, with a variation of more or less $2^{\circ} \mathrm{C} \mathrm{min}-1$. After the end of the thermal treatment process, only the air circulation of the oven was left on, until the temperature of $30^{\circ} \mathrm{C}$ was reached. The wood thermal modification process was performed at five or six temperature ranges (Table 1). For each range the thermal treatment was performed with three repetitions.

In order to perform the thermal modification process, seven wooden boards of $6 \times 16 \times 56 \mathrm{~cm}$ (thickness $\mathrm{x}$ width $\mathrm{x}$ length) were used, being placed in a metal box with a lid and separated by iron bars of $1 \mathrm{~cm}$ in diameter. This procedure was performed in order to allow gases to circulate around all the sides of the wood. Besides that, nitrogen gas was injected in the box with the objective of avoiding the wood oxidation.
Aiming at keeping the homogeneity of the thermal treatment in the thermal modification box, the temperature inside the boards was monitored by five temperature sensors, placed on the first and sixth boards out of the seven, from top to bottom, being called upper board and lower board. Five K type thermocouple sensors were connected to the data acquisition system Agilent. The depth the temperature sensors were installed was of $3 \mathrm{~cm}$; two of them were placed at $3 \mathrm{~cm}$ from the extremities and the other one in the center, all of them at $8 \mathrm{~cm}$ widthwise (Figure 1).

Three temperature sensors were used for the upper board and two for the lower one. However, the positions of the temperature sensors were defined as front upper board, when placed near the box lid; central upper board, when placed on the center of the board; back upper board, when placed on the back of the thermal modification box; front upper board, when placed near the box lid; and central lower board, when placed on the center of the board.

\subsection{Assays with subterranean xylophagous termites at laboratory}

The experiment was conducted at the Wood Biodeterioration Laboratory of the Department of Forest

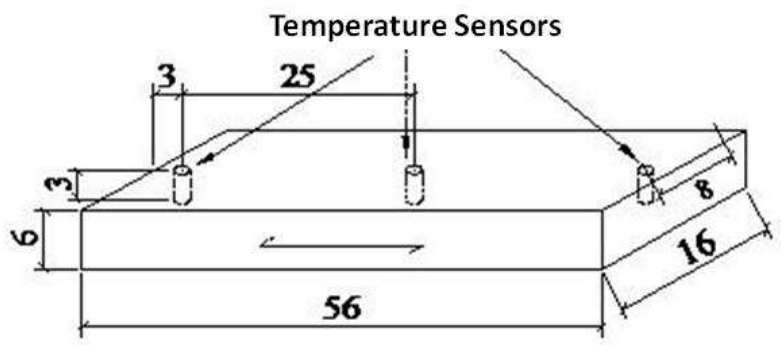

Figure 1 - Position of temperature sensors on the wooden boards (dimensions in $\mathrm{cm}$ ).

Figura 1-Posição dos sensores de temperatura nas Planchas de madeira (dimensões em $\mathrm{cm}$ ).

Table 1 - Initial and final temperatures of the ramp for each thermal modification temperature range and wood species. Tabela 1 - Temperaturas inicial e final para cada faixa de temperatura de modificação térmica e espécies de madeira.

\begin{tabular}{|c|c|c|c|c|c|c|c|}
\hline \multirow[t]{2}{*}{ Species } & \multirow[t]{2}{*}{ Temperature } & \multicolumn{6}{|c|}{ Temperatures and Final Plateaus $\left({ }^{\circ} \mathrm{C}\right)$} \\
\hline & & 160 & 180 & 200 & 220 & 240 & 260 \\
\hline \multirow[t]{2}{*}{$\overline{\text { Corymbia citriodora }}$} & Initial & 120 & 110 & 110 & 105 & 105 & - \\
\hline & Final & 170 & 190 & 210 & 225 & 245 & - \\
\hline \multirow[t]{2}{*}{ Pinus taeda } & Initial & 110 & 110 & 105 & 105 & 105 & 105 \\
\hline & Final & 170 & 190 & 205 & 225 & 245 & 265 \\
\hline
\end{tabular}


and Wood Science, Agricultural Science Center of the University of Espírito Santo, in the city of Jerônimo Monteiro, Espírito Santo State, Brazil.

In order to evaluate the biological resistance of the thermal treated wood to xylophagous termites, test samples of $2.54 \times 0.64 \times 2.54 \mathrm{~cm}$ (radial $\times$ tangential $\times$ longitudinal) were made. Aimed at simplifying the visual analysis of the termites attack, the samples were sanded to eliminate defects.

The assay was performed in accordance to the American Society for Testing and Materials - ASTM D - 3345 (2012), and to simplify the termites collection and the experiment establishment, some changes, suggested by Paes (1997), were adopted 600-mL bottles were filled with $200 \mathrm{~g}$ of sand, sterilized at $130 \pm 2{ }^{\circ} \mathrm{C}$ for 48 hours.

For the analysis of wood resistance to subterranean termites, the samples were dried in an oven at $103 \pm$ $2{ }^{\circ} \mathrm{C}$ for 48 hours. After they had cooled, they were weighed in order to find the anhydrous mass. The samples were then transferred to the bottles, adding and 37 $\mathrm{mL}$ of distilled water, so that the sand would reach $75 \%$ of its capacity to retain water, and $1 \pm 0.05 \mathrm{~g}$ of the subterranean termite Nasutitermes corniger, which corresponds to \pm 350 individuals, being $88 \%$ workers and $12 \%$ soldiers (same proportion of the colony).

After adding the termites, the bottles were slightly closed, aiming at allowing them to be aerated. A total 10 repetitions were performed for each wood species and thermal modification temperature. These samples were obtained from three randomly selected boards of each thermal treatment adopted. The bottles were kept in a climatized room $\left(25 \pm 2{ }^{\circ} \mathrm{C}\right.$ and $65 \pm 5 \%$ of relative humidity), for 28 days.

In order to analyze the thermal modification efficiency regarding the wood resistance, the mass loss $(\%)$, the damage caused by the termites on the wood (Table 2) and the number of days for the termites to die were computed. The mass loss was corrected by submitting samples to the same conditions of the experiment, but with no termites.

In order to compare the wood resistances of Corymbia citriodora and Pinus taeda concerning thermal modification temperatures, submitted to the assay, a completely randomized design was used, with 10 replications for each wood and thermal modification
Table 2 - Evaluation of the waste caused by the termites in test samples.

Tabela 2 - Avaliação do desgaste causado pelo ataque dos cupins nas amostras testadas.

\begin{tabular}{lc}
\hline Types of Waste & Rating (Note) \\
\hline Sound, surface nibbles permitted & 10 \\
Light attack & 9 \\
Moderate attack, penetration & 7 \\
Heavy & 4 \\
Failure & 0 \\
\hline
\end{tabular}

temperature. To possibility the statistical analysis, as suggested by Stell and Torrie (1980), the data on percentage of mass loss, were transformed into arcsin [root (mass loss/100)], and the waste values (note) and the number of days till the termites death were transformed into root [(note or days $)+0.5]$. Such transformations were needed to enable the data normality (Lilliefors test) and the homogeneity of variances (Cochran test). For the assays evaluation, the Tukey's test was used at 5\% significance for the significant factors according to the F test. In the first stage of analysis the effect of treatment temperature was evaluated for each species separately, as for the pine wood was adopted a temperature more. In the second stage to allow comparison between species (factorial $2 \times 6$ ) was excluded from the very last temperature adopted for the pinewood.

\section{RESULTS}

For the thermal treated wood of Corymbia citriodora, the analysis of variance accused significance at $1 \%$ for the mass loss and termites' mortality and at $5 \%$ for the damage caused by these insects on the wood. As for the Pinus taeda wood, there was significant difference at $1 \%$ for all the studied variables. The mean values were compared by the Tukey's test (Table 3 ).

It is possible to observe on Table 3 that the lowest mass loss was obtained at the temperature of $240{ }^{\circ} \mathrm{C}$. However, the damage caused by the termites at this temperature was higher than the observed at $100^{\circ} \mathrm{C}$ (control). The number of days for the termites' mortality was similar to the obtained for the control $\left(100^{\circ} \mathrm{C}\right)$, except at the temperature of $160^{\circ} \mathrm{C}$.

It is possible to observe on Table 3 that the wood of Pinus taeda presented lower mass loss at the temperature of $260^{\circ} \mathrm{C}$, being 6.54 times lower than the mass loss of the control $\left(100^{\circ} \mathrm{C}\right)$. 
Table 3 - Comparison of means for mass loss, waste and mortality caused by the termite Nasutitermes corniger in thermal treated wood of Corymbia citriodora and Pinus taeda.

Tabela 3 - Comparação de médias para a perda de massa, desgaste e mortalidade causada pelo ataque do cupim Nasutitermes corniger nas madeiras de Corymbia citriodora e Pinus taeda tratadas termicamente.

\begin{tabular}{|c|c|c|c|}
\hline $\begin{array}{l}\text { Thermal Treated } \\
\text { Temperature }\left({ }^{\circ} \mathrm{C}\right)\end{array}$ & Mass Loss (\%) & Waste (Note) & Mortality (Days) \\
\hline 100 & $2.24 \pm 0.03 \mathrm{~b}$ & $9.34 \pm 0.37 \mathrm{a}$ & $14.40 \pm 2.46 \mathrm{~b}$ \\
\hline 160 & $3.20 \pm 0.02 \mathrm{a}$ & $8.86 \pm 0.45 \mathrm{ab}$ & $20.10 \pm 4.15 \mathrm{a}$ \\
\hline 180 & $2.10 \pm 0.03 b$ & $8.84 \pm 1.18 \mathrm{ab}$ & $13.40 \pm 2.27 \mathrm{~b}$ \\
\hline 200 & $1.92 \pm 0.02 \mathrm{~b}$ & $8.82 \pm 0.35 \mathrm{ab}$ & $15.30 \pm 2.71 \mathrm{~b}$ \\
\hline 220 & $0.80 \pm 0.01 \mathrm{c}$ & $8.40 \pm 0.83 b$ & $15.10 \pm 1.37 \mathrm{~b}$ \\
\hline 240 & $0.41 \pm 0.01 \mathrm{~d}$ & $8.28 \pm 0.65 \mathrm{~b}$ & $14.90 \pm 1.45 \mathrm{~b}$ \\
\hline \multicolumn{4}{|c|}{ Pinus taeda } \\
\hline $\begin{array}{l}\text { Thermal Treated } \\
\text { Temperature }\left({ }^{\circ} \mathrm{C}\right)\end{array}$ & Mass Loss (\%) & Waste (Note) & Mortality (Days) \\
\hline 100 & $3.86 \pm 0.02 \mathrm{ab}$ & $9.26 \pm 0.35 \mathrm{a}$ & $16.60 \pm 2.17 \mathrm{a}$ \\
\hline 160 & $5.31 \pm 0.14 \mathrm{a}$ & $9.10 \pm 0.44 \mathrm{a}$ & $14.90 \pm 2.60 \mathrm{ab}$ \\
\hline 180 & $3.88 \pm 0.01 \mathrm{ab}$ & $8.82 \pm 0.88 \mathrm{a}$ & $15.50 \pm 2.17 \mathrm{ab}$ \\
\hline 200 & $2.96 \pm 0.01 \mathrm{ab}$ & $9.20 \pm 0.31 \mathrm{a}$ & $13.00 \pm 2.45 \mathrm{~b}$ \\
\hline 220 & $2.69 \pm 0.01 \mathrm{ab}$ & $8.64 \pm 0.43 \mathrm{a}$ & $15.60 \pm 0.70 \mathrm{ab}$ \\
\hline 240 & $2.12 \pm 0.01 \mathrm{~b}$ & $7.26 \pm 0.73 b$ & $15.30 \pm 1.06 \mathrm{ab}$ \\
\hline 260 & $0.59 \pm 0.01 \mathrm{c}$ & $6.96 \pm 0.78 \mathrm{~b}$ & $14.20 \pm 2.04 \mathrm{ab}$ \\
\hline
\end{tabular}

Means followed by the same letter, in each section, do not differ one to another (Tukey; $p>0.05$ ).

When comparing the species, Pinus taeda and Corymbia citriodora, at the thermal treated temperatures that are common to both, it is possible to observe that the isolated effect of temperature and species (mass loss) and the interactions between the species and the temperature (waste and mortality) were significant at $1 \%$. The effect of the temperature and species and the implications of the interactions between species and temperature were analyzed by the Tukey's test at $5 \%$ significance (Table 4 ).

Table 4 - Comparison of means for mass loss, waste and mortality caused by the termite Nasutitermes corniger in thermal treated wood of Corymbia citriodora and Pinus taeda.

Tabela 4 - Comparação das médias para a perda de massa, desgaste e mortalidade causada pelo cupim Nasutitermes corniger em madeiras de Corymbia citriodora e Pinus taeda tratadas termicamente.

\begin{tabular}{|c|c|c|c|c|}
\hline \multirow{2}{*}{$\begin{array}{l}\text { Thermal Treated } \\
\text { Temperature }\left({ }^{\circ} \mathrm{C}\right)\end{array}$} & \multicolumn{2}{|c|}{ Mass Loss(\%) } & \multicolumn{2}{|c|}{ Mass Loss (\%) } \\
\hline & & \multicolumn{2}{|c|}{ Corimbya citriodora } & $\overline{P i n u s ~ t a e d a}$ \\
\hline 100 & \multicolumn{2}{|c|}{$3.05 \mathrm{ab}$} & & \\
\hline 160 & \multicolumn{2}{|c|}{$4.26 \mathrm{a}$} & & \\
\hline $\begin{array}{l}180 \\
200\end{array}$ & \multicolumn{2}{|c|}{$\begin{array}{l}3.00 \mathrm{ab} \\
2.44 \mathrm{bc}\end{array}$} & B & $3.47 \mathrm{~A}$ \\
\hline 220 & \multirow{2}{*}{\multicolumn{2}{|c|}{$\begin{array}{c}1.74 \mathrm{~cd} \\
1.27 \mathrm{~d}\end{array}$}} & & \\
\hline 240 & & & & \\
\hline Thermal Treated & \multicolumn{2}{|c|}{ Corymbia citriodora } & \multicolumn{2}{|c|}{ Pinus taeda } \\
\hline Temperature $\left({ }^{\circ} \mathrm{C}\right)$ & Waste (Note) & Mortality (Days) & Waste (Note) & Mortality (Days) \\
\hline 100 & $0.36 \mathrm{Aa}$ & $14.40 \mathrm{Bb}$ & $9.26 \mathrm{Aa}$ & $16.60 \mathrm{Aa}$ \\
\hline 160 & $8.86 \mathrm{Aab}$ & $20.10 \mathrm{Aa}$ & $9.10 \mathrm{Aa}$ & $14.90 \mathrm{Bb}$ \\
\hline 180 & 8.84 Aab & $13.40 \mathrm{Bc}$ & $8.82 \mathrm{Aa}$ & $15.50 \mathrm{Ab}$ \\
\hline 200 & $8.82 \mathrm{Aab}$ & $15.30 \mathrm{Ab}$ & $9.20 \mathrm{Aa}$ & $13.00 \mathrm{Bc}$ \\
\hline 220 & $8.40 \mathrm{Ab}$ & $15.10 \mathrm{Ab}$ & $8.64 \mathrm{Aa}$ & $15.60 \mathrm{Aab}$ \\
\hline 240 & $8.28 \mathrm{Ab}$ & $14.90 \mathrm{Ab}$ & $7.26 \mathrm{Bb}$ & $15.30 \mathrm{Ab}$ \\
\hline
\end{tabular}

Means followed by the same small letter vertically, or the same capital letter horizontally, in each parameter, do not differ one to another (Tukey; $\mathrm{p}>0.05$ ). 


\section{DISCUSSION}

Regarding the wood from Corymbia citriodora (Table 3), the highest mass loss caused by termites attack was found at the temperature of $160^{\circ} \mathrm{C}$. This very temperature caused waste similar to the one found in the control, temperature at which the termites stay alive for a longer period of time. Gunduz et al. (2009) mentioned that the desirable changes on wood begin at $150^{\circ} \mathrm{C}$, which was not observed on this research regarding the attack of termites from Nasutitermes genus. Therefore, the temperature of $160^{\circ} \mathrm{C}$ must not be recommended for wood thermal treated of Corymbia citriodora to improve its biological resistance to termites.

The subjectiveness of the data on waste (note), evaluated as recommended by ASTM D - 3345 (2012), might have led to some difficulties to evaluate due to internal cracks (cracks in honeycomb pattern) that occurred during the thermal modification process, as mentioned by Poncsák et al. (2006), and when termites attacked the borders of these cracks, there seemed to be a higher waste.

Based on the mass loss (Table 4), it can be inferred that the wood from Pinus taeda was less resistant than from Corymbia citriodora. The thermal modification temperature that had as a result a higher resistance to termites (lower mass loss) was $240^{\circ} \mathrm{C}$, which did not differ from $220^{\circ} \mathrm{C}$ as in regard to mass loss of the samples. The explosion to the temperatures of 160 and $180^{\circ} \mathrm{C}$ resulted in mass losses similar to the control $\left(100^{\circ} \mathrm{C}\right)$. At $200^{\circ} \mathrm{C}$, the woods responded by having an intermediate behavior compared to the ones exposed to 100,180 and $220^{\circ} \mathrm{C}$.

As for the damage (Table 4), it was observed that only at $240{ }^{\circ} \mathrm{C}$ the species statistically differed, as the wood from Pinus taeda had a more severe attack of termites for this wood, the most severe termites attack was at $240{ }^{\circ} \mathrm{C}$. The same happened at 220 and $240{ }^{\circ} \mathrm{C}$ for the wood from Corymbia citriodora. However, this wood when exposed to temperatures of 160, 180 and $200{ }^{\circ} \mathrm{C}$ responded by having an intermediate behavior, between the most and the least attacked woods, at $100{ }^{\circ} \mathrm{C}$ (control).

Concerning the number of days till the death of the termites (Table 4), explosion to 220 and $240{ }^{\circ} \mathrm{C}$ provided similar resistances to the woods from both species. At 160 and $220^{\circ} \mathrm{C}$, the wood resistance was higher for Corymbia citriodora than for Pinus taeda. However, at 100 (control) and $180^{\circ} \mathrm{C}$, the wood from Pinus taeda was more resistant.

Thus, it can be stated that the adopted thermal treated temperatures, except $160^{\circ} \mathrm{C}$, provided an increase in the resistance of the woods to the xylophagous termites used in this study; such results agree with what was found by Homan et al. (2000), Borges; Quirino (2004), and Korkut; Mektas (2008), when it comes to the effect of thermal treated on the improvement of wood resistance to fungal degradation.

\section{CONCLUSIONS}

When wood from Corymbia citriodora was exposed to thermal treatment at 220 and $240{ }^{\circ} \mathrm{C}$, the resistance to the termite Nasutitermes corniger increased, and when exposed to $160^{\circ} \mathrm{C}$, the wood resistance decreased.

As for wood from Pinus taeda, the thermal modification temperatures that provided a higher resistance to the used termite were 240 and $260^{\circ} \mathrm{C}$ and the temperature that caused the resistance to decrease was $160^{\circ} \mathrm{C}$.

For thermal treated woods exposed to higher temperatures, there might have been cracks in honeycomb pattern inside the samples which, as the termites attacked the borders of such cracks, might have led to the false impression that those samples were more damaged due to the increased crack borders.

\section{ACKNOWLEDGMENTS}

To São Paulo Research Foundation (FAPESP), Brazil, for the scholarship and financial support given to this research.

\section{REFERENCES}

\section{AMERICAN SOCIETY FOR TESTING AND} MATERIALS. ASTM D - 3345: Standard method for laboratory evaluation of wood and other cellulosic materials for resistance to termite. West Conshohocken: 2012.5p.

BORGES, L.M.; QUIRINO, W.F. Higroscopicidade da madeira de Pinus caribea var. hondurensis tratada termicamente. Biomassa \& Energia, v.1, n. 2, p.173-182, 2004. 
DUCHEZ, L.; GUYONNET, R. Principles and applications of wood modification. Online at http:techtp.com/twpapers/fao, 2002.

ESTEVES, B.M.; PEREIRA, H.M. Wood modification by heat treatment: a review. BioResources, v.4, n.1, p.370-404, 2008.

GOMES, J.I.; FERREIRA, G.C. Durabilidade natural de quatro madeiras amazônicas em contato com o solo. Belém: Empresa Brasileira de Pesquisa Agropecuária, 2002. p.1-3. (Comunicado técnico, 66)

GUNDUZ, G.; KORKUT, S.; AYDEMIR, D.; BEKAR, I. The density, compression strength and surface hardness of heat treated hornbeam (Carpinus betulus) wood. Maderas. Ciencia y Tecnologia, v.11, n.1, p.61-70, 2009.

HOMAN, W.; TJEERDSMA, B.; BECKERS, E.; JORISSEN, A. Structural and other properties of modified wood. In: Proceedings of the Fifth World Conference on Timber Engineering, CIB-W18, Bern, CD-ROM. 2000. Bern: 2000.

KORKUT, S.; BEKTAS, I. The effects of heat treatment on physical properties of uludag fir (Abies bornmuelleriana Mattf.) and scots pine (Pinus sylvestris L.) woods. Forest Products Journal, v.58, n.3, p.95-99, 2008.

OLIVEIRA, J.T.S. Caracterização da madeira de eucalipto para a construção civil. 1998. São Paulo. Tese
(Doutorado em Engenharia Civil) - Escola Politécnica, Universidade de São Paulo, São Paulo, 1998.

PAES, J.B. Efeitos da purificação e do enriquecimento do creosoto vegetal em suas propriedades preservativas. 1997. Tese (Doutorado em Ciência Florestal) Universidade Federal de Viçosa, Viçosa, MG, 1997.

PAES, J.B.; MORAIS, V.M.; LIMA, C.R. Resistência natural de nove madeiras do semiárido brasileiro a fungos xilófagos em condições de laboratório. Revista Árvore, v.28, n.2, p.275-282, 2004.

PINCELLI, A.L.P.S.M.; BRITO, J.O.; CORRENTE, J.E. Avaliação da termorretificação sobre a colagem da madeira de Eucalyptus saligna e Pinus caribaea var. hondurensis. Scientia Forestalis, v.1, n.61, p.122-132, 2002.

PONCSÁK, S.; KOCAEFE, D.; BOUAZARA, M.; PICHETTE, A. Effect of high temperature treatment on the mechanical properties of birch (Betula papyrifera). Wood Science and Technology, v.1, n.40, p.647-663, 2006.

RENDEIRO, G. Combustão e gasificação de biomassa sólida: soluções energéticas para a Amazônia. Brasília: Ministério de Minas e Energia, 2008.

STEL, R.G.D.; TORRIE, J.H. Principles and procedures of statistic: a biometrical approach. 2nd ed. New York: Mc Graw Hill, 1980. 